\title{
Effects of Climate Change Variability on Agricultural Productivity
}

\author{
Tamiru Lemi* and Fekadu Hailu \\ Department of Natural Resource Management, Ethiopia
}

Submission: January 04, 2019; Published: February 06, 2019

*Corresponding author: Tamiru Lemi, Natural Resource Management Specialized in Forest and Nature Management, Ethiopia

Abstract

Globally, climate change is a challenge facing humans and their socio-economic activities, health, livelihood, and food security and is the most serious threat that adversely affects agricultural productivity; it will influence temperature and rainfall. The objective this review is to assess the effect of climate change and variability on agriculture. To achieve this objective different literature from different sources were collected, organized and summarized carefully. Even though, it is global problem, developing countries like Africa, are the most adversely affected by climate change due to low level adaptive capabilities of the countries. Climate change and agriculture are inextricably linked. Agriculture still depends fundamentally on the weather. In many parts of the world climate change has already caused a negative impact on agriculture, because of increasingly severe weather patterns. Similarly, year to year crop production substantially influenced by Climate variability even in high yield and high-technology agricultural areas. Its impacts of on agriculture have significant consequences on livelihoods, food production, and the overall economy of countries, particularly those with agriculture-based economies in the developing world by affecting crop production, livestock productivity, horticultural crops, aquaculture (fish production), apiculture. It is expected to continue to cause floods, worsen desertification and disrupt growing seasons.

Keywords: Adaptive capacity; Susceptibility; Livestock; Aquaculture; Apiculture; Crop production; Global warming

\section{Introduction}

Climate change is the worldwide environmental threats that seriously affect agricultural productivity and it affects mankind in numerous ways, including its direct influence on food production [1]. Even though the climate change is global, developing countries, like Africa is the most adversely affected by climate change due to their low level of adaptive capabilities $[2,3]$. The livelihoods of millions of peoples who are poor and susceptible are presently threatened by Climate change which altering the natural and physical resources they depend on generally and agricultural production particularly [4]. The impacts of existing and predicted changes in climate fluctuate across economies and those climate change sensitive sector such as agricultural sectors are the most affected as well as the contribution to livelihood, production and employment in such countries, economic cost is high given the agricultural sector's [5]. Furthermore, poor countries can incur huge costs from a small deviation in climate, particularly due to their poor adaptive capacity, lack of technology, and lack of resources to deal with climate change. Agricultural crop such as: - barley, maize, and wheat output was lost amount to 40 million tons since 1981 (or US $\$ 5$ billion as of 2002) annually due to global warming [6].

Most of central Asia is located mainly in arid and semi-arid areas, with agriculture being an important economic sector and source of livelihoods in the region; Therefore, the regional agriculture was challenged by climate change and within the region the distributional consequence of climate change may probable be twisted against the poorer farmers [7]. When compared with global average, the climate of the region has been changing more rapidly since 1950s [8]. Temperate areas are likely to gain from climate change, whereas, tropical and arid areas are likely to lose [9].

Many countries in tropical and sub-tropical regions are expected to be more vulnerable to climate change which will affect their marginal water balance and harm their agricultural sectors. Like other continents of the world, Africa is the one under pressure from climate stresses and is highly vulnerable to the impacts of climate variability which accounted one third of African people (i.e. 220 million are exposed to drought each year) [10]. However, different research has been done on tropical countries on the extent damage of climate variability on agricultural productivity. In Africa and some parts of the worlds, climate change is expected to change the dynamics of drought, rainfall and heat waves, and prompt secondary stresses such as the spread of pests, increased competition for resources, and consequent biodiversity losses [1]. Most of African agriculture's are vulnerable to climate change due to agricultural systems remain mainly rain-fed and underdeveloped, because of the majority of Africa's farmers are small-scale farmers with 
few financial resources, limited access to infrastructure, and disparate access to information [11]. The expected damage from climate change to African agriculture is ranged from $0.13 \%$ to $2 \%$ of GDP by 2100 [12]. Because of its dependence on agriculture which is highly susceptible to weather and climate variables such as temperature, precipitation, and light and extreme events and low capacity for adaptation, Sub-Saharan Africa has been described as the most vulnerable region to the impacts of global climate change. Many studies have been carried out to illustrate the effect of climate change and variability on agriculture. Therefore, the overall objective of this review is to asses, organize and summarize different finding on the impact of climate change on the agriculture.

\section{The Effect of Climate Change Variability and Change on Crop Production}

Long-term mean climate change will have significance impacts on global food production and may require ongoing adaptation, greater risks to food security may be posed by changes in year-to-year variability and extreme weather events [13]. Historically, low precipitation events have been attributed many of the largest falls in crop productivity $[14,15]$. However, even small changes in mean annual rainfall has an impact on productivity [13]. Climate response function indicated that, West Africa suffers the greatest losses amounting between $36 \%$ and $44 \%$ of the losses for the entire continent which means this damage represent losses between $42 \%$ and $60 \%$ of agricultural GDP in this region whereas, the Sahara countries suffers the lowest absolute damages because of agriculture in the Sahara has low value [12].

Changes in temperature, rainfall and severe weather events are expected to reduce crop yield in many regions of the developing world, particularly sub-Saharan Africa and parts of Asia [13]. Crop yields show a strong correlation with temperature change and with the duration of heat or cold waves and differ based on plant maturity stages during extreme weather events [16]. Crop productivity increase slightly at mid to high latitudes for local mean temperature increases of up to $1-3^{\circ} \mathrm{C}$ depending on the crop, and then decrease beyond that in some regions. At lower latitudes, especially seasonally dry and tropical regions, crop productivity decrease for even small local temperature increases $\left(1-2^{\circ} \mathrm{C}\right)$, which would increase risk of hunger [17] and warmer weather was expected to bring longer growing seasons in northern areas, and plants everywhere were expected to benefit from carbon fertilization $[18,19]$.

Crop production is the most significantly influenced by Climate variability year to year, even in high yield and hightechnology agricultural areas [19]. Similarly, the crop yield can be increased with irrigation application and precipitation increase during the crop growth; meanwhile, crop yield is more sensitive to the precipitation than temperature. The growing period will reduce, and the planting date also needs to change for higher crop production with climate change. Climate change can decrease the crop rotation period, so farmers need to consider crop varieties, sowing dates, crop densities and fertilization levels when planting crops [20]. The positive effects of climate change on agriculture are concerned with the $\mathrm{CO} 2$ concentration augment, crop growth period increases in higher latitudes and montane ecosystems; the negative effects include the increasing incidence of pests and diseases, and soil degradation owing to temperature change (Lal, 2005) [21]. According to Alawa et al. [22], the worldwide redistribution of disease vectors, that is, the animals, insects, microorganisms and plants that transmit diseases which are already upon Nigeria, could increase due to climate change. Crop yields in Africa, western Asia and Middle East could reduce by $15-35 \%$, and $25-35 \%$ respectively, due to increase in average global temperatures of just two to four degrees Celsius above pre-industrial levels [23].

On the other hand, crop water productivity is an important index to evaluate water saving and water investments. It is concerned with water saving irrigation is dependent on the groundwater level and evapotranspiration. It can be increased significantly if irrigation is reduced and the crop water deficit is widely induced. In the decreased precipitation regions, the irrigation amount will increase for optimal crop growth and production, but this may decrease crop water productivity [19]. Climate change impacts on water balance will present changes in soil water storage, groundwater level, soil moisture status and can provide some information about irrigation quantity. The water balance will change with precipitation and evapotranspiration, and the resultant fluctuations in soil moisture status [24]. Climate change is expected to result in decreased fresh water availability (surface and groundwater) and reduced soil moisture during the dry season, while the crop water demand is expected to increase because of increased evapotranspiration caused by climate change and the continuous introduction of high-yielding varieties and intensive agriculture. Increase in temperature, evapotranspiration, variable rainfall patterns and interactions of other meteorological parameters may have negative effects on irrigation crop water requirements (ICWR). For better management of available resources and irrigation agricultural productions, it is important to understand crop water requirements CWR, current level of water supplies and possible effects of climate change in future [25].

\section{The Effect of Climate Change Variability and Change on Horticulture}

Many studies indicated that horticultural production is affected by climate change especially rising temperature can affect breaking dormancy of many perennials' crops. Climate change is seriously affected horticultural production and productivity. Rainfall patterns and unpredictable high temperature are the two major parameters of climate change that has far reaching implications on agriculture in general and horticulture [26]. Increasing soil salinity affects Vegetable production particularly in irrigated croplands which provide $40 \%$ of the world's food [26]. Horticultural crops such as Fruits, 
vegetables, flowers, medicinal plants and tubers are grown from tropical to temperate, and other horticultural crops like spices and plantation crops are specialist species [26]. Sustainability of horticulture industry is seriously challenged by Climate change poses to human and places incomparable pressure [26]. The fluctuation of temperature alters physiological function of horticultural crop such as respiration rate, alter photosynthesis rate and partitioning of photosynthates to economic parts; which lead to alter the phenology, shorten the crop duration, days to flowering and fruiting, hasten fruit maturity, ripening and senescence [27].

\section{Effect of Climate Change and Variability on Poultry Production}

All poultry producer agrees that, poultry production is an exceptional means in poverty alleviation due to the quick income and low investment [28]. Poultry production improvement Creating an opportunity for development of the poor section of the society [29]. However, Climate change affects egg and meat production pattern, because of feed intake of poultry birds and more energy is needed to conserve the heat caused by high temperature [28-31] (ICAR 2010). On the other hand, climate change is also having an adverse effect on the distribution of poultry diseases in general and moist climatic conditions encouraged the distribution and development of diseases $[29,30]$. Tropical countries are the most affected parts by climate change, where a common practice is to house the birds in the open side sheds [28].

\section{The Effect of Climate Change Variability and Change on Livestock Production}

An important agricultural commodity for global food security which provides $17 \%$ of global kilocalorie consumption and $33 \%$ of global protein consumption is from livestock products [32]. The livestock sector subsidizes to the livelihoods of one billion of the poorest population in the world and creates a job opportunity near to 1.1 billion people [33]. The growing demand of livestock products and its rapid growth in developing countries caused "livestock revolution" [34,35]. Worldwide milk production is expected to increase from 664 million tonnes (in 2006) to 1077 million tonnes (by 2050), and meat production will double from 258 to 455 million tonnes [36].

However, climate change unfavorably affects livestock production through competition for natural resources, quantity and quality of feeds, food security, livestock diseases, heat stress and biodiversity loss [34]. Therefore, the problem is to sustain a balance between productivity, household food security, and environmental protection [35]. Most of the critical factors for livestock production, such as water availability, animal production, reproduction and health were affected by temperature. Livestock diseases are also mostly due to an increase in temperature and precipitation variation [37]. From the same source it is indicated that, livestock production in arid and semiarid regions affected by an increase of $\mathrm{CO} 2$ on pasture whereas positive impacts in humid temperate regions and forage quality and quantity is determined by the length of growing season which determines the duration and periods of available forage.

Increasing temperature and decreasing precipitation is suffering livestock, but because livestock do not have the same limitations as crops there are potential benefits to expanding acreage [38]. The direct effects of air temperature, humidity and wind speed capable of influencing growth rate, milk production, wool production and reproduction have been reported by [39]. The quantity and quality of livestock feed stuffs such as pasture and forage can be indirectly affected by climate change significantly influencing farmers' livestock selection choices. Climate change enhanced the severity and distribution of livestock diseases and parasites.

In summary, climate change is likely impact on livestock production in four main ways: these are impact on pasture, animal feed resources, animal production and disease induced due to climate change. According to Nicole [40] warmer temperatures in winter and increased carbon dioxide levels may lead to higher pasture growth rate, total annual production is likely decline due to less water availability. Pastures availability, quantity and nutritional quality are higher During rainy season whereas poor nutritional quality with high fiber and low protein contents during dry seasons which often results in declining the animal production. Due to declining of animal production, rural communities, losing livestock assets could trigger a collapse into chronic poverty and have a lasting effect on livelihoods [41]. The most sensitive diseases are those that are indirectly transmitted especially those that require vehicle for transfer from host to host (water- and food-borne disease) or an intermediate host or vector as part of its life cycle [42].

\section{The Effect of Climate Change Variability and Change on Fish Production}

Health and functioning of the ecosystems determined the productivity of a fishery on which it depends for food, habitat and even seed dispersal [43]. As noted in Ipinjolu et al. [44], the effects of climate change on fisheries and aquaculture could be negative or positive depending on the severity and extremity of the shift in the climate elements. Fisheries is particularly vulnerable because aquatic habitats directly absorbed and stores part of the solar heat energy, most fish species are cold blooded and majority of the physico-chemical parameters, and the quality of water bodies, interrelate with the water temperature.

The few measurements of physico-chemical and biological properties available are irregular measurements of temperature, salinity, dissolved oxygen, nutrients, primary production and benthic species. The impacts of changing climate on these properties of water bodies are expected to have different unintended consequence in each case on output potential and uses. Rising temperatures reduce levels of dissolved oxygen and increase metabolic rates of fish which lead to increase in fish 
deaths, decline in production, increase in feed requirements and increasing the risk and spread of disease [45]. Changes in rainfall will cause a spectrum of changes in water availability ranging from droughts and shortages to floods and will reduce water quality [46]. The invasive species are presumed to be in competition with native fish species in seas [47]. The sea level rise; available stocks of commercial importance; the total area of wetlands that bring changes in biodiversity, fishing ground characteristics would be greatly diminished and migration of fish to and from their spawning and feeding grounds affected. A generalized change in sea temperature could expected to lead to a degraded environment for the ichthys-fauna (fishlike) and to a possible decrease in the productive potential of inland waters [48].

Table 1: Twenty national economies most vulnerable to the impacts of climate change on fisheries and aquaculture (with IFAD Regional Division indicated).

\begin{tabular}{|c|c|}
\hline Rank & Country \\
\hline 1 & Angola \\
\hline 2 & Congo \\
\hline 3 & Russia \\
\hline 4 & Mauritania \\
\hline 5 & Senegal \\
\hline 6 & Mali \\
\hline 7 & Sierra Leone \\
\hline 8 & Mozambique \\
\hline 9 & Niger \\
\hline 10 & Peru \\
\hline 11 & Morocco \\
\hline 12 & Bangladesh \\
\hline 13 & Zambia \\
\hline 14 & Ukraine \\
\hline 15 & Malawi \\
\hline 16 & Uganda \\
\hline 17 & Zimbabwe \\
\hline 18 & Cote d'Ivoire \\
\hline 19 & Yemen \\
\hline 20 & Pakistan \\
\hline
\end{tabular}

Source: Allison et al. [48].

Fish stocks on which are exploited commercially are affected directly and indirectly by climate change. The direct effects of climate changes act on physiology and behavior that change growth, reproductive capacity, mortality and distribution, whereas, indirect effects change the important requirement for fish survival and reproduction such as: -productivity, structure and composition of the marine ecosystems [49]. The associations between fisheries and their ecosystems are deeper and more significant than those that exist in mainstream agriculture [50]. The ecosystem health and functioning on which it depends for food, habitat and even seed dispersal is the key factor on productivity of a fishery [43]. The most harmful to fish production are: -the increment of temperature and acidity, lower dissolved oxygen and changes to salinity [51]. Temperature and primary production are particular characteristics of the aquatic environment which will be affected by climate change (Table 1) [48].

\section{The Effect of Climate Change and Variability on Apiculture}

Honeybees are preserved mainly for honey production in Europe and across the world [52,53]. It is an important of the world's economy and trade of natural honey was worth US\$ 3.3 billion in 2011 [54]. The global production of honey over the last half century has been a steadily increased and the average productivity of each hive has also increased [55]. The production growth has outstripped in bee colonies which increased by more than a factor of two [53].

However, the climate changes are adversely affecting the agricultural sector in general and apiculture particularly. Honey production is one of the most sensitive parts among agricultural practices which are directly or indirectly affected by climate variability such as temperature, precipitation, rainfall, flooding, Drought, etc. Honeybees remain active at low latitudes, while it is complete inactivate at high latitudes throughout the year [56]. Similarly, within the tropics, the activity of honeybees decreases with increasing elevation. In particular, climate change contributes to the decline in pollinators, including honeybees, and a damage of harmonization between pollinator activity and flowering $[57,58]$.

The production of honey has an extensively affected by the warming aspect of climate change. Honey bee development cycle can be influenced by climate change and it is generally agreed that each race of honey bees grows at its own rate [59]. According to, Conte \& Navajas [58], honey bees move from one geographical region to an unknown area during any kind of climate change, and therefore, sure to have measurable consequences. During harsh season, honey bees store their honey to provide them with the energy they need to survive until favorable condition come for them. Due to these reasons the honey production and productivity became decrease and the income generated form honey became decline which collapses the economy of one country as well as the livelihoods of the community who rely on the honey production. Among the environmental factors that may impact the delivery of provisioning services by honeybees is climate change as the observed variation in honeybee abundance and honey yields along climatic gradients proposes. Temperature and to a lesser degree precipitation seem to exert a primary control on honeybee activity, yet the extent to which climate change will impact honey yields is poorly understood $[55,60]$.

\section{Conclusion}

Agriculture is the most vulnerable sector to climate change and variability. Among the agriculture sector crop production, 
livestock production, apiculture (beekeeping), horticulture and aquaculture (fish production) are the most susceptible one to climate change. Similarly, those countries who dependent on agricultural activities are affected more than those of agricultural independent countries. Climate change impacts on crop yield are often integrated with its effects on water productivity and soil water balance. Global warming will influence temperature and rainfall, which will directly have effects on the soil moisture status and groundwater level. Crop yield is constrained to crop varieties and planting areas, soil degradation, growing climate and water availability during the crop growth period. With temperature increasing and precipitation fluctuating, water availability and crop production will decrease in the future. If the irrigated areas are expanded, the total crop yield will increase; however, food and environmental quality may degrade. Soil evaporation and plant transpiration will be changed with climate change; thus, water use efficiency may decrease in the future. Improving water productivity and keeping stable relations with global food suppliers will be vital for food security.

\section{Recommendation}

Climate change has an adverse impact on agricultural sector. To reduce the impact of climate change on the production and productivity adopting and exercising different adaptation strategies is important. Among adaptation strategies: using traditional ecological knowledge, irrigation activities, water harvesting, strong policy, using advanced technology, strong institutional frame work, enable to use the existing opportunities, introducing stress tolerant crop varieties are very important to minimize the effect of climate change. In addition to adaptation strategies mitigation measurement is also play a great role in moderate the impact of climate change. Sustainable forest management, afforestation, reforestation, agroforestry practices, wetland protection are some of mitigation measure to climate change impact.

\section{Acknowledgement}

The authors would like to acknowledge Desalegn Obsi for his valuable and constructive comments.

\section{References}

1. Enete AA, Amusa TA (2016) Challenges of Agricultural Adaptation to Climate Change in Nigeria: A Synthesis from the Literature Challenges of Agricultural Adaptation to Climate Change in Nigeria: A Synthesis from the literature 1.pp. 0-11.

2. Nwafor M, Adenikinju A, Ogujiuba K (2007) The impact of trade liberalization on poverty in Nigeria: dynamic simulations in a CGE Model.

3. Jagtap S (2007) Managing vulnerability to extreme weather and climate events: Implications for agriculture and food security in Africa. Proceedings of the International Conference on Climate Change and Economic Sustainability held at Nnamdi Azikiwe University, Enugu, Nigeria, pp. 12-14.

4. Mesfin AH, Bekele A (2018) Farmers perception on climate change and determinants of adaptation strategies in benishangul-gumuz regional state of ethiopia. Journal of Food System Dynamics 9(5): 453-469.

5. Aragie EA (2013) Climate change, growth, and Poverty in Ethiopia.
6. Battisti DS, Naylor RL (2009) Historical warnings of future food insecurity with unprecedented seasonal heat. Science 323(5911): 240-244.

7. Mirzabaev A (2013) Impacts of weather variability and climate change on agricultural revenues in central asia. Quarterly Journal of International Agriculture 52(3): 237-252.

8. Gupta R, Kienzler K, Martius C (2009) Sustainable agriculture in central Asia and the Caucasus. Sustainable Agriculture in A Vision Asia and the Caucasus Sustainable Agriculture in Central Asia And Caucasus. Sustainable Agriculture in Central Asia and the Caucasus $\bullet$ Sustainable Agriculture.

9. IPCC (2007) The Scientific Basis. Contribution of Working Group I to the Fourth Assessment Report of the Intergovernmental Panel on Climate Change. In: Solomon S, et al. Cambridge University Press, New York, USA.

10. Philemon Lagat JN (2016) The effects of climate variability on livestock production in Kenya. the effects of climate variability on livestock 1(1): 58-79.

11. Pereira L (2017) Oxford research encyclopedia of environmental science climate change impacts on agriculture across Africa.

12. Mendelsohn R, Dinar A, Bank W, Dalfelt A, Bank W (2000) Climate change impacts on African agriculture. pp. 1-25.

13. Gornall J, Betts R, Burke E, Clark R, Camp J, et al. (2010) Implications of climate change for agricultural productivity in the early twenty-first century. Philos Trans R Soc Lond B Biol Sci 365(554): 2973-2989.

14. Kumar KK, Kumar KR, Ashrit RG, Deshpande NR, Hansen JW (2004) Climate impacts on Indian agriculture. Int J Climatol 24(11): 13751393.

15. Sivakumar MVK, Das HP, Brunini O (2005) Impacts of present and future climate variability and change on agriculture and forestry in the arid and semi-arid tropics. Clim Change 70(1-2): 31-72.

16. Hoffmann U (2013) Section B: Agriculture: a key driver and a major victim of global warming, in: Lead Article, in: Chapter 1, in Hoffmann, pp: $3-5$.

17. OECD (2015) Agriculture and Climate Change. Trade and Agriculture Directorate.

18. Vuren DPV, Ochola WO, Riha S, Gampietro M, Ginze H, (2009) Outlook on agricultural change and its drivers. In: McIntyre BD, Herren HR, Wakhungu J, Watson RT (Eds.), Agriculture at a Crossroads, Island Press, Washington, DC, USA.

19. Kang Y, Khan S, Ma X (2009) Climate change impacts on crop yield, crop water productivity and food security - A review. Progress in Natural Science 19(12): 1665-1674

20. Cuculeanu V, Tuinea P, Balteanu D (2002) Climate change impacts in Romania: vulnerability and adaptation options. Geol J 57(3): 203-239.

21. Lal R (2005) Climate change, soil carbon dynamics, and global food security. In: Lal R, Stewart B, Uphoff N, et al., editors. Climate change and global food security. Boca Raton (FL): CRC Press, USA, pp. 113-143.

22. Alawa DA, Asogwa VC, Ikelusi CO (2014) Measures for Mitigating the Effects of Climate Change on Crop Production in Nigeria. American Journal of Climate Change 3: 161-168.

23. Ellis S (2008) The Changing Climate for Food and Agriculture: A Literature Review. Institute for Agriculture and Trade Policy Minneapolis, Minnesota.

24. De Silva CS, Weatherhead EK, Knox JW (2007) Predicting the impacts of climate change a case study of paddy irrigation water requirements in Sri Lanka. Agric Water Manage 93(1-2): 19-29.

25. Chowdhury S, Al-Zahrani M, Abbas A (2013) Implications of climate change on crop water requirements in arid region: Department of Civil and Environmental Engineering, Water Research Group, King Fahd 
University of Petroleum and Minerals, Dhahran, Saudi Arabia. Journal of King Fahd University 28: 21-31.

26. Data S (2013) Department of Vegetable and Spice Crops, Uttar Banga Krishi Viswavidyalaya, International Journal of Science, Environment 2(4): 661-671.

27. Malhotra EK (2017) Horticultural crops and climate change: A review, Indian Journal of Agricultural Sciences 87(1): 12-22.

28. Nayak GD, Behura NC, Sardar KK, Mishra PK (2015) Effect of climatic variables on production and reproduction traits of colored broiler breeder poultry. Vet World 8(4): 472-477.

29. Adesiji GB, Tyabo IS, Bolarin O, Ibrahim M, Baba ST (2013) Effects of climate change on poultry production in Ondo state, Nigeria Ethiopian Journal of Environmental Studies and Management 6(3): 242-248.

30. Elijah OA, Adedapo A (2006) The effect of climate on poultry productivity in Ilorin Kwara State, Nigeria. International journal of poultry Science 5(11): 1061-1068.

31. Bhadauria P, Kataria JM, Majumdar S, Bhanja SK, Divya, et al. (2014) Impact of Hot Climate on Poultry Production System-A Review Journal of Poultry Science and Technology 2(4): 56-63.

32. Rosegrant MW, Fernandez M, Sinha A (2009) Looking into the future for agriculture and AKST. In: McIntyre BD, Herren HR, Wakhungu J, Watson RT (Eds.), International Assessment of Agricultural Knowledge, Science and Technology for Development (IAASTD). Agriculture at a crossroads, Island Press, Washington, DC, USA, pp. 307-376.

33. Hurst P, Termine P, Karl M (2005) Agricultural workers and their contribution to sustainable agriculture and rural development. FAO, Rome.

34. Thornton PK, Herrero M, (2010a) Potential for reduced methane and carbon dioxide emissions from livestock and pasture management in the tropics. Proc Natl Acad Sci U S A 107(46): 19667-19672.

35. Wright IA, Tarawali S, Blümmel M, Gerard B, Teufel N, et al. (2012) Integrating crops and livestock in subtropical agricultural systems. J Sci Food Agric 92(5): 1010-1015.

36. Alexandratos N, Bruinsma J (2012) World agriculture towards $2030 / 2050$

37. Rojas-downing MM, Nejadhashemi AP, Harrigan T, Woznicki SA (2017) Climate Risk Management Climate change and livestock: Impacts, adaptation, and mitigation. Climate Risk Management 16: 145-163.

38. IPCC (Intergovernmental Panel on Climate Change) (2000) Emissions scenarios. A special report of Working Group III of the IPCC. In: Nakicenovic N, Swart R (Eds.), Cambridge University Press, United Kingdom.

39. Rust JM, Rust T (2013) Climate change and livestock production: A review with emphasis on Africa. S Afri J Anim Sci 43(3).

40. Nikole frost (2014) Impacts of climate change on livestock production in South Eastern Australia.

41. IFAD (Text by Rota A, Calvosa C) (2008b) Livestock and Farming System: learning note.

42. Baumgard LH, Rhoads RP, Rhoads ML, Gabler NK, Ross JW, et al. (2012) Impact of Climate Change on Livestock Production.

43. MAB (Multi-Agency Brief) (2009) Fisheries and Aquaculture in A Changing Climate. Fao, Rome, Italy, p. 6.
44. Ipinjolu JK, Magawata I, Shinkafi BA (2014) Potential Impact of climate Change on Fisheries and Aquaculture in Nigeria. Journal of Fisheries and Aquaculture Science 9(5): 338-344.

45. FAO (2008) Climate change implications for fisheries and aquaculture. In: The State of Fisheries and Aquaculture. FAO, Rome, Italy, pp. 87-91.

46. Soliman NF (2017) Aquaculture in Egypt under Changing Climate: Challenges and Opportunities. ARCA Working Paper. Working Paper No. (4).

47. Pancucci-Papadopoulou MA, Kevrekidis K, Corsini-Foka M, Simboura N (2005) Changes in Species: Invasion of Exotic Species, State of the Hellenic Marine Environment, Hellenic Centre for Marine Research, Institute of Oceanography.

48. Allison EH, Perry AL, Badjeck MC (2009. Vulnerability of national economies to the impacts of climate change on fisheries. Fish and Fisheries 10(2): 173-196.

49. Yazdi SK, Shakouri B (2010) The effect of climate change on aquaculture, International Journal of Environmental Science and Development 1(5): 378-382.

50. FAO (2008b) Climate Change for Fisheries and Aquaculture. Technical Background Document from the Expert Consultation, 7 to 9 April 2008, FAO, Rome. Paper Presented at Climate Change, Energy and Food', High level Conference on Food Security: The Challenges of Climate Change and Bioenergy, 3-5 June Rome, Italy.

51. Roessig JM, Woodley CM, Cech JJ, Hansen LJ (2004) Effects of global climate change on marine and estuarine fishes and fisheries. Reviews in Fish Biology and Fisheries 14(2): 251-275.

52. Morse Ra, Calderone Nw (2000) The Value of Honey Bees as Pollinators of Us Crops. Bee Culture 128: 1-15.

53. Aizen MA, Harder LD (2009) The global stock of domesticated honey bees is growing slower than agricultural demand for pollination. Current Biol 19(11): 915-918.

54. FAO (2015) Food and Agriculture Organization of the United Nations.

55. Langowska A, Michał Z, Sparks TH, Adam G, Peter WT, et al. (2016) Long-Term Effect of Temperature on Honey Yield and Honeybee Phenology. International Journal of Biometeorology 61(6): 1125-1132.

56. Spiva MK (1992) The relative success of Africanized and European honey-bees over a range of life-zones in Costa Rica. Journal of Applied Ecology 29(1): 150-162.

57. Le Conte Y, Navajas M (2008) Climate change: impact on honey bee populations and diseases Rev Sci Tech 27(2): 499-510.

58. Hegland SJ, Nielsen A, Lazaro A, Bjerknes AL, Totland O (2009) How does climate warming affect plant-pollinator interactions? Ecol Lett 12(2): 184-195.

59. Millennium Ecosystem Assessment (2005) Ecosystems and Human Well-Being: Synthesis, World Resources Institute, Washington, DC, USA.

60. FAO (2004) Impact of climate change on agriculture in Asia and the Pacific. Twenty-seventh FAO Regional Conference for Asia and the Pacific. Beijing, China, pp. 17-21. 
Your next submission with Juniper Publishers will reach you the below assets

- Quality Editorial service

- Swift Peer Review

- Reprints availability

- E-prints Service

- Manuscript Podcast for convenient understanding

- Global attainment for your research

- Manuscript accessibility in different formats ( Pdf, E-pub, Full Text, Audio)

- Unceasing customer service

Track the below URL for one-step submission https://juniperpublishers.com/online-submission.php 